\title{
ОТ МОДЕРНИЗМАКПОСТМОДЕРНИЗМУ
}

\section{FROM THE MODERN TO POSTMODERNIZM}

MODERNIZMDEN POSTMODERNIZME

\section{Tamilla ALIYEVA*}

\begin{abstract}
АННОТАЦИЯ
В статье «От модернизма к постмодернизму» проводится разграничение понятий модернизма и постмодернизма. Показывается эволюция постепенного перехода от модернизма к постмодернизму. Постмодернизм старается осмыслить современную действительность и в то же время вступает в полемику с модернизмом и переосмысливает данную реальность. Если представители модернизма стремятся к будущему, ищут новые методы, подходы, подвергают критике действительность, то представители постмодернизма этого стремления не имеют и нацелены на неопределенность.

Ключевые слова: Модернизм, постмодерн, постмодернизм, интертекстуальность, восприятие, смерть автора, герменевтика, кинизм, новое мировидение.

\section{ÖZET}

Makalede modernizm ve postmodernizmin anlamlar tefrik edilmiştir. Modernizmden postmodernizme geçiş süresinin tekamülü gösterilmiştir. Postmodernizm çağdaş gerçekleri benimsemeye yönelik olup aynı zaman modernizmle tartışır ve olan gerçeğin manasını yeniden idrak eder. Modernizm temsilcileri geleceğe yönelik hareketlenirken, yeni metotlar ve yaklaşımlar keşfederken, gerçeği eleştirirken, postmodernizm temsilcilerin ise buna benzeri emeller yok ve belirsizliğe yönelmişlerdir.
\end{abstract}

Anahtar Kelimeler:Modernizm, postmodern, postmodernizm, metinleraras1l1k, yazarın ölüm algısı, hermenötik, Sinisizm, dünyanın yeni bir vizyon

\section{ABSTRACT}

Modernism and postmodernism as a modern interpretation of the world both appeared as the original protest against the reality and have created new directions in philosophy and art. Widely debated with regard to their meaning and implications, they have also been said to refer to a philosophical and cultural movement. Having been a tendency in contemporary culture, postmodernism arose as polemic with modernism and at the same time it is some kind of summarizing, reconsideration and revaluation of values. Whereas modernism aimed

* Doç. Dr. Ardahan Üniversitesi, Rus Dili ve Edebiyatı Bölümü öğretim üyesi. 
at search of definiteness and firm bases, postmodernism aims at daily occurrence, radical pluralism, vagueness and uncertainty.

Keywords: Modernism, Postmodern, Postmodernism, Intertextuality, The Perception of the Author's Death, Hermeneutics, Cynicism, A New Vision of the World.

Модернизм и постмодернизм, наиболее часто используемые сегодня термины. Исходя из названия ясно, что они отличаются и эти понятия по своей сути разные. Феномен постмодерна - это некое описание реальности, а генезис постмодерна - это объяснение явления и возникновение этого понятия. Герменевтика постмодерна - это понимание интерпретации этих явлений, которые в целом называются постмодерном, собственно говоря, феноменом постмодерна.

Постмодерн - это не партия, не течение, это не набор текстов, не группа людей. Постмодерн, как мы понимаем - это ситуация, некая реальность, которая случилась с нашим миром. Наиболее ясно эту ситуацию запечатлели некоторые философы, которых принято называть - постмодернистами, хотя, ни один из них себя сам таковым не называл. Почти никто не воспевал эту реальность, но они открывали некие новые способы мышления, которые во многом, как кажется, сегодня создали эту особую культуру постмодерна.

Постмодернсоздалновоемироощущение,понятие,котороетесносвязано $\mathrm{c}$ европейскойкультурой. Приэтомчеловекпостмодернавступал в противоречие с окружающимегомиром. Модернизм XIX-XX векаотличаетсяотпостмодерна Новоговремени. Именномодернизмсталосновойдляпоявленияновогонаправления в литературе и в другихобластяхнауки. Новоенаправление - посмодернизм опира ет ся не толь ко наидеи модер нитов, нострем итсяотличитсяотнегооп и раясь на раз личные тенденци ипарадигмы, тоестьпостмодернизмухарактерен- плюрализм.

"В тов ремякак модернизм-создавалсвоисо бственные форм ыхудожествен ногоавторитета, постмодернизм развивался в сторонухудожетвеннойанархии" (Hassan İ. 1975:25-60 ). Постмодернисты, поутверждениюфилосова Ильина, хаоспринималикакфакт, а модер ни ст ыстр емилиьзащититьсяотнадвигающегос яха оса. Модернизм большес вязан с прошлым, а не с будущим.(Никитина И.В.2004, №12:.73-80).

Модернизм состоит из разных школ: имажизм, дадаизм, экспрессионизм, конструктивизм, сюрреализм и др.Представители модернизма в русской литературе: В. Маяковский, В. Хлебников, Е. Гуро, Б. Лившиц, А. Кручёных, ранний Л. Андреев, С. Соколов, В. Лавренев, Р. Ивнев.

В тюркских литературах И. Шинаси, А. Гамид, Н. Камал, Зия Паша, Мидхад Эфенди, Али Суави, Р. Акрам, Муэллима Наджи, Назим Набизаде, Тофик Фикрет, Дженаб Шахабеддин, Сулейман Назиф, Рза Тофик, М. А. Юрдагюль, Эмин Бюленд и другие мастера слова.

Представителипосмодернизма:Ролан

Барт,Жак Лакан, Мишель Фуко,Ж. Бодрийар, Жиль Делёз, Ф. Гваттари, Ю. Кристева, Ж.Ф.Лиотар, Жак Деррида, Ричард Рорти и другие в основном все французы, но есть среди них и американцы. 
Феномен постмодернизма возник как специфическая реакция на устоявшиеся формы предшествующей культуры ведущих стран Европы, Америки. По мнению американского теоретика Фредрика Джеймисона «появление постмодернизма можно датировать со времен послевоенного бума в США с конца 40-х — начала 50-х гг., а во Франции — с установления Пятой республики с 1958 г.» (Джеймисон Ф.,2001:111122)

Сегодня постмодернистскую ситуацию в культуре выделяют в разных регионах, а самой постмодернистской страной, по мнению Жака Деррида(Деррида Ж., 1992:5357), является Япония.

Понятие постмодерна встречается в философии Лиотара как новый подход к определению философии и ее роли в жизни общества. Термин «постмодернизм» был использован в 60-е годы американским литературоведом Хассаном для описания некоторых новых явлений в американской литературе.

В России тоже есть постмодернисты, которые открывают это новое мышление и по- своему его используют, но именно Франция стала интеллектуальным центром. Кажется, что Французская литература XX века растратила себя на теорию. Действительно, во Французской литературе XX века почти ничего не появилось, но есть некая фундаментальная теория, тоестьвновоммирепостмодернап роисходитдиверсификацияфункции. Причинывозникновениядиверсификации-это взаимосвязанныепротиворечия, возникающих на макро- и микро- уровнях. В разрешении противоречий реализуются функции диверсификации: то есть происходит выравнивание развития текстов; выравнивание нормы поэтики постмодернизма; сглаживание циклического развития, выравнивания объема текста. Слово диверсификация происходит от латинских слов diversus, что означает разное, удаленный и fadere - делать. Это экономический термин, но понятие диверсификация может употребляться и в литературоведении. Диверсификация означает проникновение форм текста в новые формы, благодаря чему они превращаются в многозначимые понятия. Акцент при этом делается на создании таких видов текста, которые не связаны с основным текстом.

Если американцы создавали некий базис для существующей реальности, то французы ее осмысливали, а немцы противились до последнего. Можно сказать, что немецких постмодернистов и не было.

Постмодернизм сложился во Франции. В России о постмодернизме пишет А.Г.Дугин(Дугин А.Г.,2006:45-90)и в основном опирается на мысли выше сказанных авторов постмодернистов. Его книга «Постфилософия», -это введение в постмодернистскую реальность.

Первые попытки, серьезного осмысления постмодерна на русский язык сделал так же и И.П.Ильин(Ильин И.П., 1996:47)в работе «Постмодернизм, постст руктурализм, деконструктивизм».

Постмодернизм представляет собой своего рода реакцию на монотонность универсального видения мира в модернизме.

Выделяют четыре типа постмодернизма: первый тип опирается на традиции авангарда и ориентации на "сырую" реальность, противопоставляется высокоэлита рному искусству. Это американская контркультура 60-х годов. Первоначально постмодернисты сосредотачивали свое внимание на искусстве, позднее - 
распространились на более широкий спектр явлений современной культуры. Большинство концепций постмодерна относитсяксфереинтеллектуальныхфеноменов.

Второйтип60-70-хгодов связансразвитиемпостструкту рализма,проблематикой филосо фииязыкаидеконст рукциейтрадиционнойметафизическойпарадигмы (Ж. Деррида).

Литературные произведения, представляющие постмодернизм этого плана, т.е. канонические примеры типа: "Женщина французского лейтенанта" Джона Фаулза; "Имя

Розы "Умберто Эко; "Радуга гравитации" Томаса Пинчена; "Жизнь: способупотребления"

ЖоржаПерека.

Третья разновидность: постмодернистская поэтика. Поэтический коммерческий

постмодернизмдвижетсяврусленеоконсерватизма.

Четвертаяразновидностьзатрагиваетсоциологические,философские,психологичес киеаспектыпостмодренизма.

Это общая атмосфера упадка эпохи, реакция на типовой конформизм западной цивилизации, постмодернистский стиль жизни, модус чувствования - человека эпохи постмодернизма. Так, американский философ Р. Рорти утверждает, что истины вовсе нет, она принадлежит высказываниям и потому-"там, гденетпредложений, нетиистины" (Рорти Р. 1996).

Как показывают исследования многих европейских и американских политологов и социологов, современное развитие стран Запада не может описано как строго упорядоченное. Уже спустя десятилетия после окончания второй мировой войны в них наметился поворот к новым постмодернистским структурам и отношениям. Известные имена прошлого или герои современной эпохи не завораживают постмодерниста, размываются социальные границы, дезорганизуются большие сообщества и структуры, растет культурная фрагментаризация, игра языка, смешение жанров, мода как код культуры, экзистенциальные мотивы.

«В настоящее время торжествует не порядок, а спонтанность, неорганизованность. Прежняя односторонняя ясность целей и средств человеческого поведения и действия сменяется многообразием, неопределенностью, неясностью, сложностью, которые с трудом воспринимаются, оцениваются и с обилием ошибок осуществляются.»(Барт Р.,1989:71)

Степень отказа от культуры модернизма различными теоретиками понимается по-разному: от категорического отрицания модернистских ценностей до многообразных способов их переосмысливания. Постмодернизм, отвергает, прежде всего, модернистские ценности и стремится переосмысливать, заимствуя и эксплуатируя ранее выработанные формы.

Парадигма постмодернизма так же включает анализ термина "интертекстуальность", введенный в 1967 году теоретиком постмодернизма Ю. Кристевой, ученицы Р. Барта, пропагандиста и истолкователя идей М. М. Бахтина. 
Интертекстуальность стала одним из основных при анализе художественного произведения постмодернизма и употребляется не только как средство анализа литературного текста, но и для определения того миро- и самоощущения современного человека, которое получило название постмодернистская чувствительность. В сфере научныхинтересовКристевой- семиотика, лингвистика, литературоведение, психоанализ. Под влиянием структурализма Р. Барт, Жю Лакан, М. Фуко, Ж. Деррида и др., у Ю.Кристевой -сознание человека было отождествлено с письменным текстом. В результате все стало рассматриваться как текст: литература, культура, общество, история и сам человек. Этот взгляд привел к восприятию человеческой культуры как единого "интертекста". Концепция интертекстуальности тесно связана с теоретической "смертью субъекта" М. Фуко и "смертью автора", а также "смертью" индивидуального текста.

Юлия Кристева(Кристева Ю.,2003:36-67) считает, что человек постмодернизма, пытающийся найти себя в чем-то находит невозможное в самом себе. Это момент, когда субъект понимает, что оно само и есть нечто иное, как отвратительное. И вместо того, чтобы задаваться вопросом о своей сущности, он интересуется своим местом: он спрашивает себя скорее «Где Я?», чем«Кто Я?». Он путешественник в бесконечности и чем больше он блуждает, тем больше получает наслаждение, а это путь к его спасению.

Отвратительное, от которого он пытается скрыться- это забытые воспоминания, которые всегда возвращаются к нему. В забытом времени отвратительное должно было быть полюсом притяжения желания. Но забвение все воссоздает по-новому чистое становится грязным, добро превращается в зло, прекрасное становится уродливым. Именно, внезапно возникшее время забвения концентрирует в яркой вспышке разрядку, подобнуюгрому.

Постмодернизм - это поиск новых форм отношений человека с миром, новых ценностей и новых критериев. Постмодернизм несет в себе не только проблему исчерпанности модернистского типа сознания, а значит и культуры, которая просуществовала десятки столетий, но и проблему поиска того, что будет дальше, поиска новых принципов грядущей культуры. Сила постмодернистского мышления именно в признании культурного постмодернизма, который открывает простор для открытого

\section{диалога,освобождаетотдогматизма.}

Основные представители постмодернизма сконструировали литературу постмодернизма, которая покоится на суждении об интенциональности сознания. В сущности, предметность всякого акта сознания, то есть непременная соотнесенность c каким-либо определенным предметом, будь то предмет реальный или воображаемый.

Философов-постмодернистов относят так же и к представителями номиналистической культуры. Номинализм (лат. nотіа - "имя") - учение, согласно которому существуют только единичные вещи, а общие понятия (универсалии) - есть творение ума, в действительном мире им ничего не соответствует. Номиналистические установки постмодернизма сформировались под влиянием не только античного кинизма, но и философии языка, активно разрабатываемой такими философами и лингвистами, как Ф. Ницше, Ч. Пирс, Э. Сепир и Б. Уорф, М. Фуко, Ф. 
де Соссюр. Так, например, лингвист Ф. де Сосюр постулировал произвольность связей между словом и предметом, знаком и означаемым. М. Фуко провел генеалогические исследования в области социального конструирования языка, Э. Сепир и Б. Уорф утверждали, что язык формулирует наше восприятие действительности, что человеческий познавательный опыт заранее проструктурирован языком. Постмодернизм, напротив, отдает предпочтение разнотипности и различию как освободительным силам в переопределении культуры (Постмодернизм и культура., 1991:57).

Таким образом, постмодернистская ситуация вносит новый опыт видения и оперирования своими и чужими культурными ценностями, стимулирует интеграцию различных культур и способствует выработке целостного воззрения на мир и формирует единую и взаимодополняющую систему коммуникаций различных культур человечества.

\section{БИБЛИОГРАФИЯ:}

1. Барт Р. Избранные работы. Семиотика. Поэтика. - М., 1989.С.71

2. Деррида Ж. Письмо японскому другу // Вопросы философии. - 1992. - №4. C.53-57.

3. Джеймисон Ф. Теории постмодерна // Искусствознание. №1, 2001. С. 111122.

4. Дугин А.Г. Постфилософия. Три парадигмы в истории мысли. (Курс лекций МГУ) 2006.С.45-90

5. Ильин И.П. Постструктурализм. Деконструкция, постмодернизм. М., 1996.C.47

6. Кристева Ю.Силы ужаса: эссе об отвращении. СПб.: Алетейя, 2003, с. 36-67

7. Никитина И.В. О временах, о нравах:маскимассовойкультуры.// Человек.2004.,№12,с.73-80

8. Постмодернизм и культура. - М., 1991.С.57.

9. Рорти Р. Случайность, ирония и солидарность. М., 1996.

10. HassanI. Paracriticism:Seven Speculations of the times.Urbana/1975.P.25-60.

\section{BIBLIOGRAPHY:}

1. BartR.Izbranniyerabot1.Semiotika. Poetika.-M.,1989.S.71.

2. Derrida J.Pismoyaponskomudrugu//Voprosı filosofii.-1992.-№4.-S.53-57.

3. Djeymison F. Teoriyapostmoderna//İskusstvoznaniye.№1, 2001. S.111-122.

4. DuginA.G.Postfilosofiya. Triparadigmı v istoriimısli.(Kurs lekciy MGU).2006.S.45-90.

5. İlyin İ.P. Poststrukturalizm.Dekonstrukciyua, postmodernism.M.,1996.S.47.

6. Kristeva Yu. Silıujasa: esseob otvraşenii.SPb.:Aleteya, 2003, S.36-37. 


\section{KARADENIZ}

(Black Sea-4eproe Mope) YIl 6 Sayı 24

7. Nikitina İ.V. O vremenah o nravah: maskimassovoykulturı//Çelovek. 2004,№12, S.73-80

8. Postmodernizmi kultura.-M.,1991.S.57.

9. Rorti R. Sluçaynost, ironiya I solidarnost.M.,1996.

10. HassanI. Paracriticism:Seven Speculations of the times.Urbana/1975.P.25-60. 